\title{
Confusion over CPR in patients with covid-19
}

\author{
Francesco P Cappuccio professor of cardiovascular medicine and epidemiology and consultant \\ physician
}

University of Warwick and University Hospitals Coventry and Warwickshire NHS Trust, Coventry CV4 7AL, UK

The news on cardiopulmonary resuscitation (CPR) in covid-19 1 is the latest example of the state of confusion, denial, and unpreparedness in which national health authorities and politicians are facing the pandemic. ${ }^{2}$ The evidence provided by scientific advisers is either publicly challenged, ${ }^{3}$ not made available for scrutiny, ${ }^{4}$ or absent.

The World Health Organization lists CPR as an aerosol generating procedure, ${ }^{5}$ for which full personal protective equipment (PPE; gown, gloves, FFP3 mask, and facial protection) should be used. But the Department of Health and Social Care does not, suggesting that emergency medical staff can carry out CPR while awaiting further support. ${ }^{6}$ To add to the confusion, the NHS in the West Midlands recommends against CPR in patients with suspected or diagnosed covid-19, unless in the emergency department or if are staff wearing full PPE, thus assuming that CPR is an aerosol generating procedure. ${ }^{1}$ Appropriate PPE is not available across the whole of the NHS, and testing for covid-19 is still limited, despite official reassurances. To be prudent, we should consider most patients seen in the NHS to be infected.

Is the revised regional policy so restrictive to protect NHS staff at the expense of patients? Or are patients, health workers, and the public knowingly being put at risk? Both scenarios are equally worrying. Myocardial injury and cardiac dysfunction are associated with excess mortality from covid- $19 .{ }^{78}$ Delaying CPR because of the revised criteria could lead to avoidable fatalities. Nevertheless, lack of PPE justifies a change in the risk-benefit balance for CPR. ${ }^{9}$

The current situation shows a national system that is in disarray, unprepared, slow, confused, and impassive to frontline NHS staff and volunteers, who are applauded for their dedication but are not equipped with the PPE they require. ${ }^{10}$ Our clinical staff need adequate means to provide the best level of care, under decisive guidance and in a safe environment. ${ }^{11}$

Competing interests: None declared.

Full response at: https://www.bmj.com/content/368/bmj.m1282/rr-3.

Mahase E, Kmietowicz Z. Covid-19: Doctors are told not to perform CPR on patients in cardiac arrest. BMJ 2020;368:m1282. 10.1136/bmj.m1282 32224494

2 Horton R. Offline: Covid-19 and the NHS-"a national scandal". Lancet 2020;395:1022. 10.1016/S0140-6736(20)30727-3 32222186

3 Ferguson NM, Laydon D, Nedjati-Gilani G, et al. Report 9: Impact of non-pharmaceutical interventions (NPIs) to reduce covid-19 mortality and healthcare demand. 16 Mar 2020. https://www.imperial.ac.uk/media/imperial-college/medicine/mrc-gida/2020-03-16COVID19-Report-9.pdf

4 Alwan NA, Bhopal R, Burgess RA, etal. 36 signatories. Evidence informing the UK's COVID-19 public health response must be transparent. Lancet 2020;395:1036-7. 10.1016/S0140-6736(20)30667-X 32197104

5 World Health Organization. Modes of transmission of virus causing covid-19: implications for IPC precaution recommendations. 2020. https://www.who.int/publications-detail/modesof-transmission-of-virus-causing-covid-19-implications-for-ipc-precaution-recommendations

6 Department of Health and Social Care, Public Health Wales, Public Health Agency Northern Ireland, Health Protection Scotland, Public Health England. Covid-19: Guidance for infection prevention and control in healthcare settings. March 2020. https://www.gov.uk/ government/publications/wuhan-novel-coronavirus-infection-prevention-and-control

7 Guo $\mathrm{T}$, Fan $\mathrm{Y}$, Chen M, etal . Cardiovascular implications of fatal outcomes of patients with coronavirus disease 2019 (COVID-19). JAMA Cardiol 2020; 10.1001/jamacardio.2020.1017. 32219356

8 Madjid M, Safavi-Naeini P, Solomon SD, Vardeny O. Potential effects of Coronaviruses on the cardiovascular system. A review. JAMA Cardiol 2020 10.1001/jamacardio.2020.1286. 32219363

9 Fritz Z, Perkins GD. Cardiopulmonary resuscitation after hospital admission with covid-19. BMJ 2020;369:m1387. 10.1136/bmj.m1387 32253197

10 Siddique H, Parveen N, Topping A. Coronavirus deaths of two nurses lead to calls for more protection. $2020 \mathrm{Apr} 3$. https://www.theguardian.com/society/2020/apr/03/coronavirusdeaths-of-two-nurses-lead-to-calls-for-more-protection

11 Godlee F. Protect our healthcare workers. BMJ $2020 \cdot 369 \cdot \mathrm{m} 1324$. 10.1136/bmj.m1324 32327409

Published by the BMJ Publishing Group Limited. For permission to use (where not already granted under a licence) please go to http://group.bmj.com/group/rights-licensing/ permissions 